\title{
Study on the Strategies for the Industrialization Development of Henan Traditional Craft Arts
}

\author{
Xiaofei Zhang \\ School of Art and Design \\ Huanghe Science and Technology College \\ Zhengzhou, China
}

\begin{abstract}
The craft art industry plays an important role in the cultural industries of Henan Province and is one of the five major cultural industries prioritized in Henan Province. We should investigate the development status of Henan traditional craft art industry, put the existing problems in order, study its development trend under the major background of the construction of Central Plains economic region and put forward the sustainable development strategies for the industry, which have positive significance on promoting the great-leap-forward development of Henan cultural industries.
\end{abstract}

Keywords-craft art; industrialization development; Henan; strategies

\section{INTRODUCTION}

The construction of the region for inheritance and innovation of Chinese historical civilization is one of the five strategic positioning and is the only economic region that possesses the missions and functions for inheritance and innovation of culture in the national major function zoning and that are the high mission granted by the central authorities. Early in 2013, the Henan Provincial Government issued the Key Schemes of Development Strategies for Henan Cultural Industry and determined to position the craft art industry together with digital media, creative design, cartoon games and cultural tourism as the five major cultural industries which will be prioritized in the future in Henan and put forward the thought to accelerate the cultural industries of the whole province through key industries and promote the great-leapforward development of cultural industries. All those bring great opportunities and development space for the rapid development of Henan craft art industry. 'Recently, under the background of the combination with modern technology and culture, Henan traditional craft art gradually blends in the domestic and foreign large market. Through the marketization, some traditional crafts spring up again which effectively drives the inheritance and development of traditional crafts. However, it is incontestable that there still exist certain problems such as small scale enterprise, lower degree of intensification, aging of product, scarce capacity of independent innovation and incomplete industrial chain etc, which seriously restrict the rapid development of craft art industry. Therefore, energetic exploration of effective strategies for the marketization and industrialization development of traditional craft art industry has become the priority among priorities to promote the

Fund Project: soft science program of Henan Science and Technology Department "Study on the Strategies for the Industrialization Development of Henan Traditional Craft Arts under the Background of Construction of Central Plains Economic Region" (Program No.: 152400410272); Funding planning program for young backbone teachers of colleges and universities in Henan "Study on the Inheritance and Development of Intangible Cultural Heritages of Folk Fine Arts Type in Henan" (Program No.: 2011GGJS-221).. inheritance and development of Henan traditional craft art industry and is worthy of further research.

\section{DEVElopment Status OF HenAN TRAditionAL CRAFT ART INDUSTRY}

The massive Central Plain culture and abundant craft art resources lay the solid foundation for the rapid development of craft art industry of Henan mainly including 11 major categories of sculpture, metal, lacquer ware, knitting of natural plant fiber, embroidery and art ceramics and over 70 varieties which ensures the Central Plain to be one of the most important production regions for national craft art. With the long history, massive deposits, exquisite craftsmanship, the distinct local color, certain industry scale and local traditional features, the Henan craft art industry has become the important composition of the Henan cultural industry and also provides the favorable conditions to accelerate the development of Henan cultural industry and the construction of central plains economic region.

It is shown in the statistical yearbook of 2015 issued by Henan Province Bureau of Statistics that up to the end of 2014, there are 476 legal entities of "production of craft art articles" in the category for enterprises above designated size in cultural and relevant industries, accounting for $11 \%$ of the whole cultural and relevant industries; over 0.11 million of employees, accounting for $12.8 \%$ of all the employees in cultural and relevant industries; total capital of 50.4 billion yuan, accounting for $10.4 \%$; 78.63 billion yuan of operating income and 6.825 billion yuan of total amount of profits, accounting for 14.7. Those numbers are far more than the average value of the 12 major industry categories. In 2015, the total amount of profits of "manufacturing industry for culture and education, industrial art and sports \& entertainment products" of the industrial enterprises above designated size is 7.337 billion yuan which realizes the year-on-year growth by $14 \%$ under the condition of year-on-year reduction of provincial total amount of profits by $0.1 \%$. In the first three quarters in 2016, the prime operating revenue of "manufacturing industry for culture and education, industrial art and sports \& entertainment products" reaches to 74.262 billion yuan with the year-on-year growth by $14 \%$ and the total amount of profits is 5.596 billion yuan with the year-on-year growth by $7.7 \%$ surpassing the provincial average value by $2.7 \%$. Those numbers fully demonstrate that the manufacturing 
industry for craft art articles plays an important role in the provincial cultural and relevant industries.

During the 12th five-year plan, Henan has constructed 41 characteristic culture industry villages and 34 characteristic culture industry towns and the development of replica and imitation of cultural relics, Kaifeng embroidery, jun porcelain, Chinese $\mathrm{Ru}$ porcelain and peony porcelain and other cultural products realizes great breakthrough. The rural culture industries such as jade industry in Shifosi Zhenping County, wickerwork handiwork in Sanhejian Gushi County, peony paintings in Pingle Village Mengjin County and the Huahu Village Wanggong Village Minquan County etc are all enjoying great prestige home and abroad. The investigation conditions for the development of several traditional handicrafts are as follow:

Kaifeng embroidery: Currently, there are about over 50 enterprises manufacturing Kaifeng embroidery, of which the representing enterprises are those with large scale such as Kaifeng Embroidery Plant and Kaifeng Craft Art Research Institution. Those large scale enterprises possess the regular management but the quantity is relatively less. Most of other enterprises are workshop-type and the type of processing with customer's materials. Currently, the Kaifeng embroidery market demands are increasing with stability plus the Kaifeng embroidery possesses higher process requirements with the long manufacturing duration making it not suitable for largescale and volume production. Therefore, although the industrial competition is relatively intensified, the operation situations of enterprises are normal.

New Year wood-block print in Zhuxian Town: currently, there are mostly the private individual workshops founded in Zhuxian Town and the surrounding countries with small scale, dominated by the traditional remaining New Year prints with small quantity of innovation. Due to the recently active development of tourism industry and the intensified propaganda, the popularity is continuously promoting and the operation situations are relatively normal.

Jun porcelain in Yuzhou: in 2013, there are 197 manufacturers of Jun porcelain, 28 thousand employees and 0.786 billion of annual value of production. The Jun porcelain enterprises are centered with the Shenhu Town and the industry radiates to more than 10 surrounding towns with broad driving effects. The industrial system has reached to the considerable scale and the internal relation with coordination and distribution of responsibilities has been basically formed. There are also enough professionals. Many manufacturing enterprise of Jun porcelain are established with research and development institutions with several achievements obtaining scientific research awards of over provincial level. There are 3 masters in craft art of national level, 2 masters in ceramic art of national level, 4 inheritors of Jun porcelain, the national intangible cultural heritage, 129 masters in ceramic art and 11 inheritors of provincial intangible cultural heritage of Jun porcelain.

Jade carving in Zhenping: the processing of jade carving is spread over more than 100 administrative villages of all the towns in the whole county, of which there are 50 specialized villages, near 15 thousand specialized households for jade carving. The county possesses 10 major specialized markets for jade carving and more than 20 thousand of various boutiques of jade carving and booths, of wich the jade carving groups account for $70 \%$ of national processing groups. The various enterprises in the cultural industry park have reached to 1,621 , of which there are 1,072 cultural enterprises, accounting for $66.1 \%$, forming 10 various specialized markets of jade carving, radiating and driving the employees in jade carving out of the county for 0.25 million. The industrial value added of jade culture has been surpassing 3.5 billion in successive 3 years, accounting for over $20 \%$ of the GDP of the county. The annual business volume has reached to 6.3 billion yuan, 0.12 billion for the taxes and 0.93 billion yuan for profits. The county has become the largest jade carving and selling distribution center and the largest jade culture research and dissemination center in China.

\section{MAJOR PROBLEMS EXISTING IN THE MARKETIZATION DEVELOPMENT OF HENAN TRADITIONAL CRAFT ART}

The first is the lack of famous-brand products. Due to the division and dispersion of resources, the concentration ratio of cultural resources of Henan craft art. And there exists the conditions of unscientific and unreasonable use of resources and lacks the craft art brands famous in China or even in the world. The second is that many traditional handicraft skills are close to be lost. The creative conditions for the workers of traditional craft art is relatively poor and the remuneration for them is also poor, therefore the initiative for creation is thwarted; the situations where the offspring is not willing to learn the craftsmanship of the elders and the students are not willing to learn the skills from their teachers are very serious; due to the lack of published and acoustic image materials for inheritance, the traditional handcraft unique skills and craft art varieties are close to be lost. The third is lack of creative talents. The lack of talents for products creation especially the masters in craft art nationally well-known are and the skillful artificers is far from meeting the demands for industrial development and can't follow the trend of development of era and the change of domestic and foreign markets which has become the "bottleneck" restricting the development of Henan craft art industry. The fourth is that the protection consciousness of intellectual property is poor. After the products are designed, due to the poor intellectual property protection consciousness and ineffective precautionary measures, the original design products are imitated by others and sham products occupy the market to pass away the sham as the genuine which will hurt the interests of consumers. The five is the poor industrial centralization and scale level. The craft art industry in some places is still in the civil spontaneous status and the level of family workshop with the dispersed production distribution. The scale of regional towns, villages and streets as well as the industries and industrial parks have not formed the industrial scale which is not benefit for the industrialization and market oriented development and is not beneficial to found the industrial brands. 


\section{STUdY ON THE STRATEGIES FOR THE INDUSTRIALIZATION DEVELOPMENT OF HENAN TRADITIONAL CRAFT ART}

\section{A. Fully Understand the Functions and Position of Traditional Craft Art Industry}

The national craft art culture contains the intelligence of Chinese people, integrates the unique national temperament and artistic appreciation of Chinese nation and represents the artistic cohesion and the cultural images of the historical inheritance of Chinese nation, which is not only the cultural industry with distinct Chinese characteristics, but also is the ascendant sunrise industry flourishing with the continuous improvement of the people's living possessing great economic value, social value, cultural value, artistic value and historical value. At the same time, as the important carrier for the commercial trade between China and other countries in the world, the Chinese craft art even becomes the bridge for the communication of eastern and western civilization. It is exactly this bridge that gets the world to begin to know China and gets China to know the world and influences the world. The importance of Chinese craft art culture is self-evident. In 2012, the Ministry of Culture issued the Doubling Programme for Cultural Industry during the 12th Five-Year Plan to list the craft art into the 11 key industries. The National Bureau of Statistics revised the "standard for classification of cultural and related industries" to promote the craft art industry from the past peripheral classification into the top seven class in the top ten classes which determines the important position of craft art in cultural industries. The series of policies embody the high attention and strong support of our government on the development of craft art cultural industry. So to speak that the development of craft art industry has become the national important strategies for the promotion of cultural soft power of central authorities.

As the important component in the cultural industries, except for the great function on promoting the national soft power, the craft art industry also is the important industry related to national interest and people's livelihood, wealthy country and powerful people and the wealthy country and possession of wealth among people which bears the important tasks of prospering the market, job enlargement and servicing the "agriculture, the countryside and farmers" and is also the typical "green economy, low carbon economy and environmental protection industry" and greatly promotes the development of regional economy. More and more local governments combine with the practical regional conditions to successively focus on the development of craft art industry by taking it as the important contents for cultivating economic growth points, changing the development patterns of economy and adjusting the economic structures. A large quantity of craft art culture products with strong characteristics", "abundant connotation", "superior quality", "excellent appearance" and ecological environmental protection" have become the golden card for foreign publicity and communication.

\section{B. Integrate the Exploration of Tradition and Modernity and Innovate the Development Ways on Various Levels}

Seek for material and technical innovation. The craft art belongs to the formative arts. The creation of new materials and the improvement of manufacturing skills are the important aspects for craft art innovation. The modern motor machines and tools have appeared in the traditional sculpture field and the electric kilns have been applied in the pottery workshops and plants more frequently. For the traditional crafts suitable for volume production, the new materials and new technology shall be applied to the development of new products and new design and colors so as to feature the modern style. Taking the Kaifeng Embroidery as an example, with its production modes changing from the early hand embroidery to the sewing machine embroidery to the electric embroidery manufactured by the computer technology, the embroidery technologies are continuously innovated by the modern technology methods. Currently, some operators conduct the aided design of manuscripts for embroiders drawing through computers and the efficiency for the drafts completion of the painters is greatly improved. Although compared with traditional embroider works, this improvement will exert certain negative impacts, this improvement also meets the increase of market demands to a certain degree which reflects, on a side, the importance of correct treatment of traditional handicraft and modern technologies.

Innovate fashionable products. The traditional folk crafts shall be continuously self-regulated according to the development of era to adapt to the era demands. Due to the changes on living environment, whether on the substance functions or the aesthetic tastes, the handiworks should find new approaches to give play to their own functions and value. The craft art enterprises should change the thoughts to adapt the demands for era development on one hand, and to further promote the function of "serving the people" combining with active development of new products meeting the daily lives of the people on the other hand. Henan Yihan Kaifeng Embroider Co., Ltd. always keeps on the product innovation and the enterprise has achieved rapid development recently. The Yihan Kaifeng Embroider takes the Kaifeng embroider life, embroider art and embroider decoration as objectives. The Kaifeng embroider life is mainly represented by the scarves, shawl, handbags and cheongsam in Kaifeng embroider; the Kaifeng embroider art is represented by the Riverside Scene at Qingming Festival, peony painting, landscape painting and figure painting in Kaifeng embroider; the Kaifeng embroider decoration emphases on the high and middle end customization of the decorative pictures and screens in Kaifeng embroider for hotels, real estate, enterprises and public institutions and government etc. Henan Yihan Kaifeng Embroider Co., Ltd. was successfully listed on the stock market in Shanghai Equity Transaction Trusteeship Center which makes it the only listed enterprise in the Kaifeng embroiders industry.

\section{Further Improve the Intensive Production of Craft Art Products}

It is imperative to intensify the construction of industrial cluster and characteristic economy regions, cultivate the craft 
art industrial bases, intensify the construction of craft art industrial parks and accelerate the construction of specialized villages (towns) of craft art industry. To further cultivate and develop the subjects of cultural market, promote the concentrated development level of cultural industry and enhance the overall strength and core competitiveness of cultural industry, the Henan Provincial Government agreed the Implementation Schemes for the "Double-Ten" Project of Henan Cultural Industry formulated by the Provincial leading group office for cultural system reform and development in June 2013. In 2016, the six parks including Kaifeng ancient city of Song capital cultural industry park, Xuchang Jun porcelain cultural creative industry park; Zhenping County (Shifosi Town) jade culture industry park and the Ruzhou Ru porcelain e-commerce industry park etc are named the key culture industry park in Henan Province. Taking the Zhenping County (Shifosi Town) jade culture industry park as an example, Zhenping County relies on the long jade culture history, special jade carving technology and other advantages and takes the construction of "China Jade Capital" as objective to accelerate to create the national jade culture industry exemplary park integrating with the sales of jade raw gemstone, manufacturing and processing of jade carving, boutique sales exhibition of jade carving and the research and dissemination of jade culture. The county is striving to construct the parks to be more scientific, to better comply with the regulations and features of cultural industry development, to better represent the high-level planning in current era, to possess more prospective and maneuverability and to be more beneficial to the stable development of Zhenping jade culture industry. Currently, Nanyang jade curving has formed the cultural brands with abundant jade culture connotation and special charm and has become the pillar industry obtaining the rapid development.

\section{Further Improve the Market System for Craft Art Industry}

Accelerate the specialization of craft art and the construction of high-end market, promote the combination of craft art industry and modern tourism industry and promote the harmonious development of culture resources and craft art industry. With the planning layout for the development of tourism, actively encourage and guide the craft art enterprises and craft art masters to create the tourist souvenirs with abundant local color, rely on the characteristic scenic spots to establish the exclusive shops of tourist commodities, construct and open the characteristic handicraft studio or workshops etc, guide the public to accept, love and consume the craft art creative products and cultivate the product market environment. Rely on the exhibition brands to promote the industrial development and expand the sales of crafts. The China Nanyang Expo of Jade Carving and Gemstones is originated from the 1993 Nanyang (Zhenping) International Jade Carving Festival which was held once a year. Since 2002, the expo was upgraded from the city level to be held by Henan Province and was officially renamed as "Nanyang Jade Carving Festival" which was hosted by the Gems and Jewelry Trade Association of China and the People's Government of Henan Province. Through the development of over a decade, the jade carving festival has formed a large-scale integrated economic and cultural activities integrating with jade and flower appreciation, tourism, economic and trade cooperation and communication which has played important functions in the promotion of rapid development of Nanyang jade carving industry.

\section{E. Intensify the University-Industry-Research Cooperation Between Craft Art Industry and Local Colleges}

The craft art industry should take the colleges as the source and intelligent support of craft art to actively develop the university-industry-research cooperation. At the same time, intensify the cooperation of local colleges and craft art enterprises to develop the research on crafts and products and promote the university-industry-research cooperation which have important driving effects on the transformation development of local colleges. Xuchang University has made very valuable exploration on the development of Jun porcelain industry. Yuzhou in Xuchang is one of the "first eight cultural reform and development experimental areas in Henan Province" which puts forward the objective of "insisting on the carrier of Jun porcelain culture, insisting on paying equal attention on the inheritance and innovation and remodeling the Jun porcelain brands". The Xuchang University cooperated with Yuzhou Jun Porcelain Research Institution to set up the porcelain art design major in Henan Province in 2003 and established the "Jun Porcelain Culture and Industry Research Center of Xuchang University" and "Xuchang China Jun Porcelain Research Institution" in 2013. The academy of fine arts and the Micro-Nano Material Research Institution all conducted active exploration on the Jun porcelain modeling, sintering technology and glaze development and other aspects and achieved great achievements. The virtuous circle of refining the Jun porcelain culture through Jun porcelain industry and guiding the sound development of Jun porcelain industry by using the Jun porcelain culture has already been formed. In 2015, Baofeng County and the Pingdingshan University signed the cooperation agreement on ceramic development and the academy of ceramic of Pingdingshan University has become the ceramic research and training base in Baofeng County. The unification of the two energetic parties will better promote the development of ceramic industry in Baofeng County and improve the talent quality for ceramic industry. At the same time, the both parties give play to their own talent, production and sales advantages to promote the thorough exploration of industry-university-research and greatly promote the development of $\mathrm{Ru}$ porcelain industry.

\section{F. Promote the Interactive Development of Craft Art Industry and Creative Industry}

In February 2014, the "Several Opinions on the Promotion of Culture Creativity and the Integrated Development of Design Service and Related Industries of the State Council" was issued which clearly put forward that the culture inheritance, technology support, encouragement of culture creativity and the design service should rely on the abundant local culture resources to promote the creativity and design connotation and to expand the approaches for the inheritance and utilization of tangible and intangible cultural heritages. There are many categories in the craft art industry in our province being listed in the national and provincial intangible cultural heritage directory. For the further development and 
growth, the interactive development of culture creativity industry should be paid with high attention. The culture creativity has become the new engine for the development of traditional craft art development. Based on the development and inheritance of craft art skills, actively use the creative design thoughts and creatively develop the new products of craft art with era spirits, practicability, daily use and industrialization and further enhance the brands so as to realize the characteristic and sustainable development.

\section{CONCLUSION}

Henan craft art industry is the carrier to inherit history and carry forward the outstanding central plain culture. As long as we can correctly find the development orientation and strategies for traditional craft art, it will certainly promote the great-leap-forward development of Henan culture industry and will exert active facilitation to the construction work of the inheritance and innovation region for Huaxia historic civilization exclusive in central plain economic region.

\section{REFERENCES}

[1] Huang Baoqing. Strategic Thinking on the Promotion of Contemporary Craft Art Industry Development[J]. Academic Review. 2015 (01)

[2] Yao Qinghua. Study on the Central Plain Folk Arts Resources[M]. Beijing: Economy and Management Publishing House, 2014.

[3] Zhenping: Enlarge and Enhance the Jade Carving Industry, Strive to Construct the Chinese Jade Capital[N/OL].http://henan.sina.com.cn/nanyang/economy/2016-0428/080745920.html.

[4] Zhou Zhengsheng. Several Thoughts on the National Craft Art Industry Development under the "New Normal”[N/OL].http://www.cnaca.org/info/2015713/1-1939.shtml. 